\title{
Green Nanoarchitectonics of Silver Nanoparticles for Antimicrobial Activity Against Resistant Pathogens
}

\author{
Gabriela Pereira Chuy ${ }^{1}$ Pâmela Cristine Ladwig Muraro ${ }^{2}$ - Altevir Rossato Viana ${ }^{2}$. Giovani Pavoski ${ }^{3}$. \\ Denise Crocce Romano Espinosa ${ }^{3} \cdot$ Bruno Stefanello Vizzotto $^{1} \cdot$ William Leonardo da Silva ${ }^{2}$ (])
}

Received: 11 October 2021 / Accepted: 15 November 2021 / Published online: 23 November 2021

This is a U.S. government work and not under copyright protection in the U.S.; foreign copyright protection may apply 2021

\begin{abstract}
Antimicrobial resistance represents a serious concern to public health, being responsible for hospital infections, affecting mainly immunosuppressed patients. Thus, nanotechnology appears as an alternative to solve this problem, through the application of metallic nanoparticles with antimicrobial activity. The present work aims to synthesize and characterize AgNPs from Klebsiella pneumoniae (AgNPs-KP) and Aloe vera extract (AgNPs-AV), evaluating the antimicrobial activity against Klebsiella pneumoniae carbapenemase $(\mathrm{KpC})$ and the cytotoxicity in the L929 cell line. AgNPs were prepared by the biosynthetic method using Klebsiella pneumoniae and were characterized by XRD, FTIR and SEM-EDS. Antimicrobial activity was tested using the MIC and MBC. The cytotoxicity was evaluated by the MTT method and neutral red. The production of ROS and nitrogen RNS tests were performed in the L929 cell line. Thus, it was possible to confirm the production of AgNPs$\mathrm{KP}$, through morphological, structural and elemental analysis. AgNPs from Klebsiella pneumoniae had potent antimicrobial activity in low concentration against antimicrobial resistant pathogens with MIC $9.76 \mu \mathrm{g} \mathrm{mL}^{-1}$ and MBC $9.06 \mu \mathrm{g} \mathrm{mL}{ }^{-1}$. Moreover, AgNPs-KP in concentrations of 10,30 and $100 \mu \mathrm{gL}^{-1}$ did not show cytotoxic properties for the L929 fibroblast, where only the cytotoxic effect was observed in high concentrations $\left(300 \mu \mathrm{gL}^{-1}\right)$. AgNPs-KP did not produce ROS about the analyzed concentrations and RNS production was only in the highest concentration of $3000 \mu \mathrm{g} \mathrm{mL} \mathrm{L}^{-1}$. Therefore, AgNPs biosynthesized by Klebsiella pneumoniae have potential medical applicability as a promising antimicrobial agent, using a simple and low-cost method, correlating nanomedicine as nanostructured materials.
\end{abstract}

Keywords Green Nanotechnology $\cdot$ Nanomaterials $\cdot$ Metallic nanoparticles $\cdot$ Bacterial resistance $\cdot \mathrm{KpC}$

\section{Introduction}

Antimicrobial resistance (AMR) is one of the main problems faced by human health, occurring when bacteria, viruses, fungi, and parasites change over time and no longer respond to medicines making infections harder to treat and increasing the risk of disease spread [1]. Thus, these agents are responsible for the increase in patients' mortality in hospitals, promoting a significant increase in the cost of human

William Leonardo da Silva

w.silva@ufn.edu.br; williamleonardo_silva@ hotmail.com

1 Biomedicine Course, Franciscan University, Santa Maria, RS, Brazil

2 Nanoscience Graduate Program, Franciscan University, Santa Maria, RS, Brazil

3 Polytechnical School of Chemical Engineering, University of the São Paulo, São Paulo, SP, Brazil health, given the need for more expensive drugs and longer hospital stays [2, 3]. For example, WHO announced at World Antimicrobial Awareness Week 2020 that the overuse of antimicrobials during the Covid-19 pandemic caused by SARS-CoV-2 could accelerate the emergence and spread of bacterial resistance.

There is an urgent need to develop new effective alternatives to solve the problem of resistance, associating nanotechnology with health science, to combine the synergistic effects of nanomaterials with their specific properties [4-8]. Recently, the application of nanomaterials with antibacterial activity, such as silver (AgNPs) $[9,10]$ and zinc nanoparticles [11], has been attracted due to the flexibility on the application of these nanoparticles (such as on surfaces infected for bacteria) and due to the possibility to obtain low-cost materials using green synthesis (biosynthesis).

The synthesis process of metallic nanoparticles through physicochemical methods involves the use of a series of 
toxic reagents and non-renewable sources, a fact that motivates the need to propagate more sustainable methodologies [12]. Thus, green nanotechnology and sustainable development have been used to combinate eco-friendly environmentally technologies, for example, the microorganisms have been explored such as biocatalysts potential for the AgNPs synthesis, showing a series of advantages, such as considerable yield, non-toxic characteristics, and low cost [13].

Noteworthy that the AgNPs synthesized from bacterial strains showed greater antibacterial activity in comparison with metallic nanoparticles synthesized by physicochemical methods, due to the presence of proteins that can interact with biomolecules, resulting in greater biocompatibility, which can act mainly in cell lysis, through a change in membrane potential, loss of cytoplasmic material and inhibition of the respiratory chain [14-17].

The porosity and high specific area of the silver nanoparticles allow them to cross cell membranes, being easily absorbed and capable of causing damage to cells. Therefore, to enable a new alternative with a potential medical application, it is necessary to analyze the cytotoxic potential of nanoparticles [18-22].

In this context, the present work aims to synthesize and characterize silver nanoparticles using biosynthesis process from Klebsiella pneumoniae (ATCC 700603) and Aloe vera extract, evaluating the antimicrobial activity against resistant pathogens Klebsiella pneumoniae carbapenemase $(\mathrm{KpC})$ and the cytotoxicity in the L929 cell line (murine fibroblasts).

\section{Materials and Methods}

\subsection{Preparation of Klebsiella pneumoniae Bacterial Culture}

Klebsiella pneumoniae (ATCC 700603) was cultivated in Mueller-Hinton broth (MHB, HiMedia ${ }^{\circledR}$ ) and incubated for $18-24 \mathrm{~h}$ at $37 \pm 2{ }^{\circ} \mathrm{C}$ in a bacteriological incubator of the Molecular Biology Laboratory of the Franciscan University (UFN).

\subsection{AgNPs Biosynthesis}

Silver nanoparticles were prepared from Aloe vera extract with $\mathrm{AgNO}_{3}$ (and $10^{-3} \mathrm{~mol} \mathrm{~L}^{-1}$ ) such as metallic precursor, according to the literature [23] (Method 1). Thus, $5 \mathrm{~mL}$ of Aloe vera extract were added with $5 \mathrm{~mL}$ of $\mathrm{AgNO}_{3}$, followed the addition of the $5 \mathrm{~mL}$ of $\mathrm{NH}_{4} \mathrm{OH} 37 \%$ solution, under magnetic stirring $\left(120 \mathrm{rpm}, 25^{\circ} \mathrm{C}\right)$ during $90 \mathrm{~min}$ until precipitation. After $24 \mathrm{~h}$, the supernatant was discharged, and bottom product was submitted to drying $\left(80^{\circ} \mathrm{C}\right)$ in an oven overnight. The sample was labeled AgNPs-AV. Figure 1 shows a schematic representation of the biosynthesis process of silver nanoparticles.

Silver nanoparticles also were prepared by the biosynthetic method (Method 2), using MHB containing the Klebsiella pneumoniae and metallic precursor $\left(10^{-3} \mathrm{~mol}\right.$ $\mathrm{L}^{-1} \mathrm{AgNO}_{3}, 99.9 \%$, Sigma Aldrich () , at the ratio of $1 \%$ $(\mathrm{v} / \mathrm{v})$, according to the literature [24]. After, the solution was placed under radiation $(75 \mathrm{~W} / 30 \mathrm{~min})$, where the appearance of brown color in the reaction suggested the formation of AgNPs, followed by contact with a water bath system $\left(56^{\circ} \mathrm{C}\right.$ for $30 \mathrm{~min}$ ) for precipitation to occur. Thus, discarding the supernatant, the precipitate was dried $\left(60^{\circ} \mathrm{C}\right.$ for $\left.24 \mathrm{~h}\right)$ and labeled AgNPs-KP.

\subsection{Characterization}

XRD analysis was used to investigate the crystallinity of AgNPs, using Bruker D2 Phaser Diffractometer with cupper tube $\left(\mathrm{K}_{\mathrm{\alpha Cu}}=0.15418 \mathrm{~nm}\right)$, in range of the $5^{\circ}-70^{\circ}$, with acceleration tension and applied current of $30 \mathrm{kV}$, and $30 \mathrm{~mA}$, respectively. FTIR was used to identify the functional group using a Perkim Elmer spectrometer (Spectrum One model) at transmittance mode operation at range of $4000-450 \mathrm{~cm}^{-1}$, with $4 \mathrm{~cm}^{-1}$ resolution and 32 runs. Scanning Electron Microscopy coupled to Energy Dispersive Spectroscopy (SEM-EDS) was used to verify the morphology of the AgNPs using Phenom Prox Scanning Electron Microscope (Thermo Fisher Scientific model), operating at $15 \mathrm{kV}$ voltage and $100 \mu \mathrm{m}$ of amplitude with around $2550 \times$ magnification. Dynamic light scattering (DLS) was used to evaluate the diameter of the AgNPs-KV using NanoBrook Omni equipment (Brookhaven Instrument Corporation, New York) equipped with red laser diode $(35 \mathrm{mV}$, $\lambda=640 \mathrm{~nm}$ ) at detection angle of $90^{\circ}$. Moreover, the procedure was carried out in triplicates by using BIC Dynamic Light Scattering Particles Sizing Software, version 1.2.1.0 (USA).

\subsection{Antibacterial Activity}

Antimicrobial activity of AgNPs was carried out by microdilution method for nine clinical isolates of $\mathrm{KpC}$, determining the minimum inhibitory concentration (MIC) in 96-well plates according to the literature [25]. Suspensions containing the microorganisms were prepared in MHB cation adjusted, regulated to $0.5 \mathrm{McF}$ arland scale $\left(1.5 \times 10^{6}\right.$ $\mathrm{UFC} \mathrm{mL}^{-1}$ ), and bacterial inoculums diluted to 1:20 factor. After, serial dilutions of the AgNPs (5000-0.009 $\mu \mathrm{g} \mathrm{mL}^{-1}$ ) were carried out in $100 \mu \mathrm{L}$ of MHB, followed by the addition of $10 \mu \mathrm{L}$ of bacterial inoculums. Microwells containing only the culture medium were considered the negative control, while the wells containing the media and microorganisms without any effective constituents were considered 


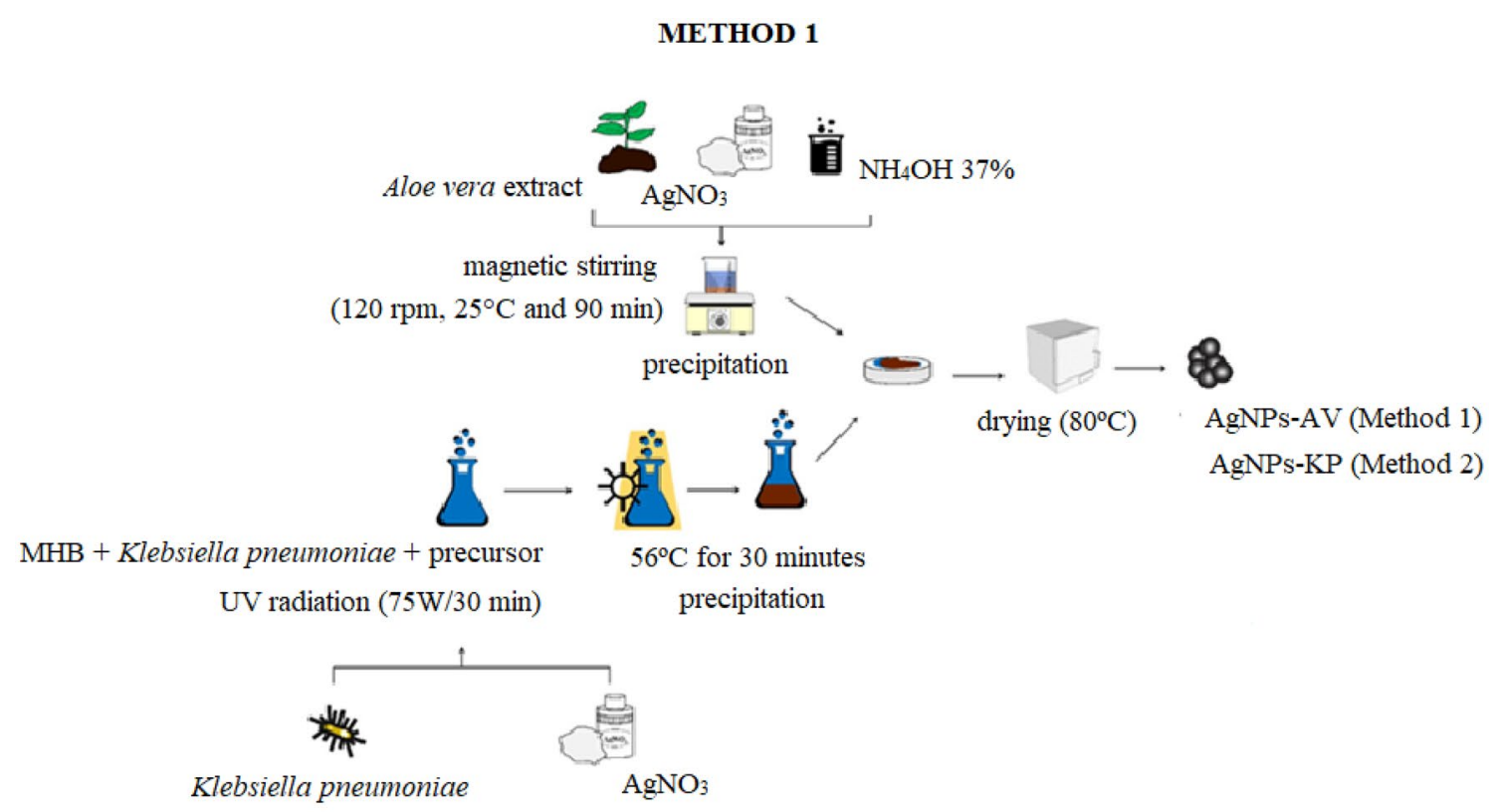

(a)

METHOD 2

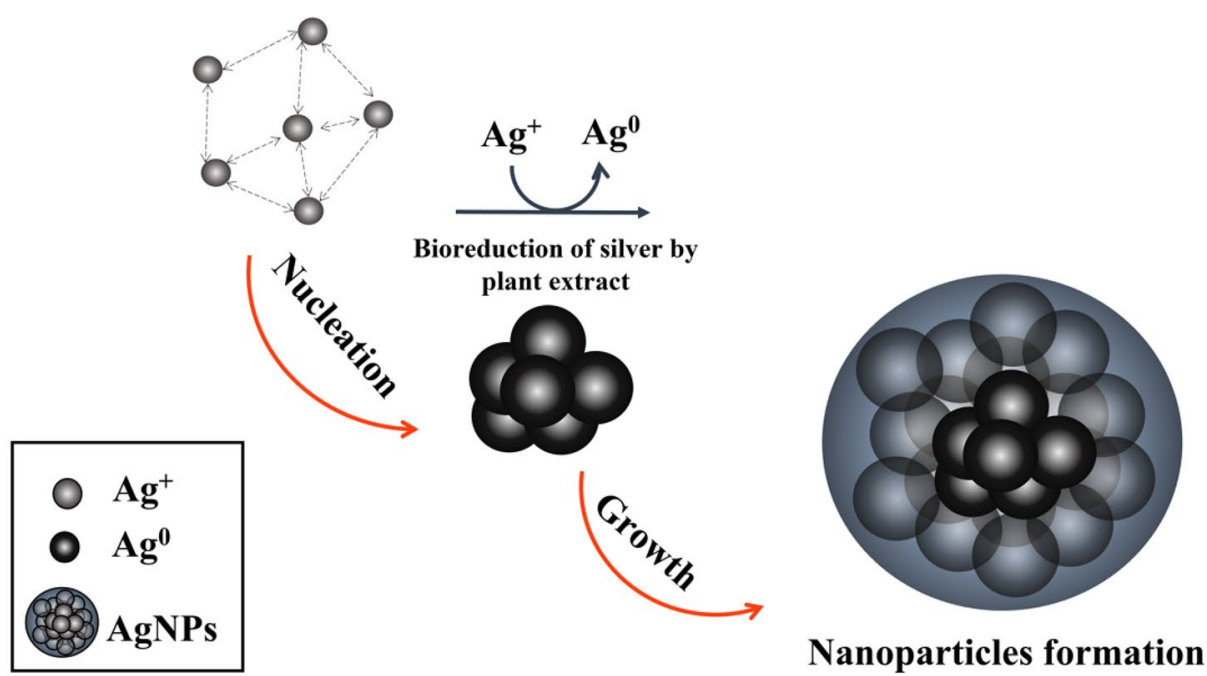

(b)

Fig. 1 a Schematic representation of the AgNPs biosynthesis process from Aloe vera extract and Klebsiella pneumoniae and $\mathbf{b}$ AgNPs formation process

positive growth control. Plates were incubated for $18-24 \mathrm{~h}$ at $37 \pm 2{ }^{\circ} \mathrm{C}$ under aerobic conditions. After, $20 \mu \mathrm{L}$ of triphenyl tetrazolium chloride (TTC, $10 \mathrm{mg} \mathrm{mL}^{-1}$ ) were added to each microwell, followed by re-incubation for $2 \mathrm{~h}\left(37 \pm 2{ }^{\circ} \mathrm{C}\right)$. Then, readings of MIC were visually performed, with the change color of the solution (from colorless to red) being as indicative of bacterial growth. Thus, MIC was defined as the lowest AgNPs concentration able to inhibit bacterial growth.
Figure 2 shows AgNPs dilution in the culture media as well as microorganisms distribution in 96-well plates.

Moreover, minimal bactericidal concentration (MBC) was determined by spreading on the surface of MC agar plates. Thus, $15 \mu \mathrm{L}$ of the content of the wells at concentrations equal to and above the MIC, where the plates were incubated for $18-24 \mathrm{~h}$ at $37 \pm 2{ }^{\circ} \mathrm{C}$ in a bacteriological incubator and checked for visible growth. The lowest concentration 
Fig. 2 Representation of the microdilution method performed in 96-well plates using $\mathrm{AgNPs}$ to $\mathrm{KpCX}$ and $\mathrm{KpCY}$. * $\mathrm{KpCX}$ and $\mathrm{KpCY}$ exemplify the distribution of diferente bacterial strains analyzed in the assay on a plate. Where: $1 \mathrm{~A}-1 \mathrm{H}$ : negative control; $2 \mathrm{~A}-2 \mathrm{H}$ : positive control; $3 \mathrm{~A}-12 \mathrm{~B}$ to $5000 \mu \mathrm{g} /$ $\mathrm{mL}$ until $0.009 \mu \mathrm{g} / \mathrm{mL}$ using AgNPs-KP (KpCX); 3 C-12 D to $5000 \mu \mathrm{g} / \mathrm{mL}$ until $0.009 \mu \mathrm{g} /$ mL using AgNPs-AV (KpCX); $3 \mathrm{E}-12 \mathrm{~F}$ to $5000 \mu \mathrm{g} / \mathrm{mL}$ until $0.009 \mu \mathrm{g} / \mathrm{mL}$ using AgNPs-KP (KpCY); $3 \mathrm{G}-12 \mathrm{H}$ to $5000 \mu \mathrm{g} /$ $\mathrm{mL}$ until $0.009 \mu \mathrm{g} / \mathrm{mL}$ using AgNPs-AV (KpCY)

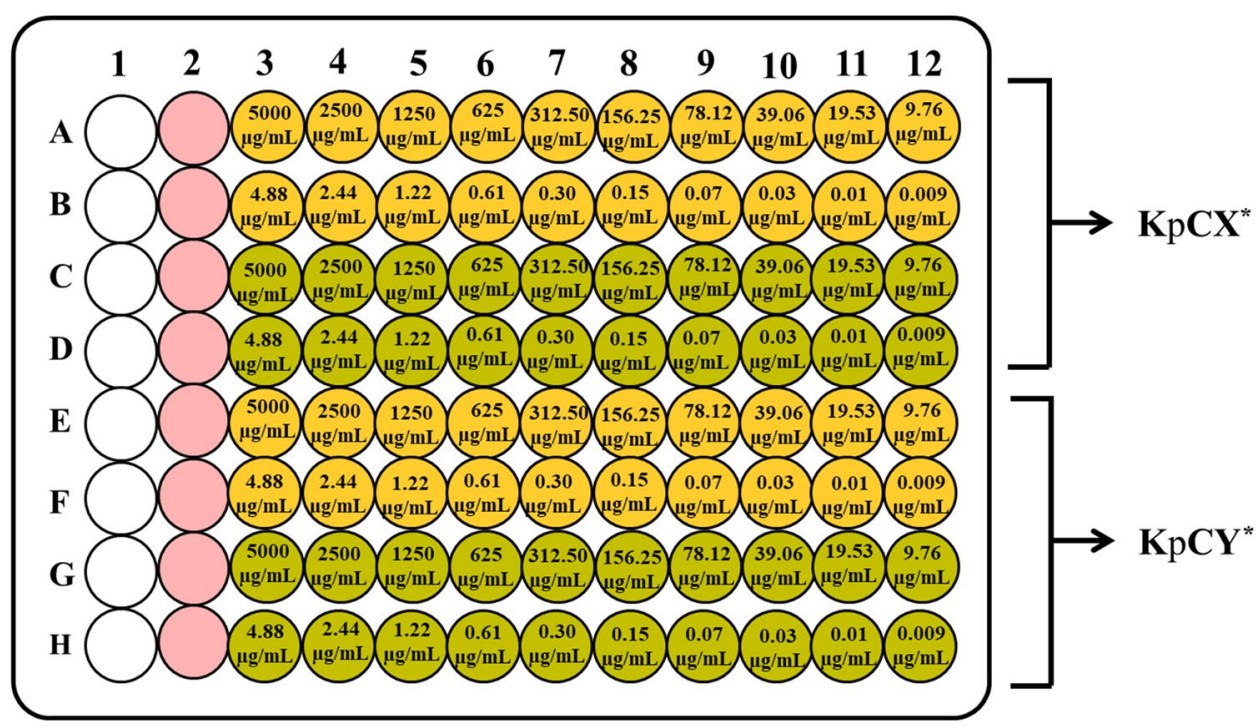

of AgNPs that prevented visible growth on agar plates was determined as the MBC.

\subsection{Cytotoxicity}

The cytotoxicity assay was performed by the MTT method (3-(4,5-Dimethylthiazol-2-yl)-2,5-Diphenyltetrazolium Bromide) which is based on the reduction of the tetrazolium salt (yellow color) in insoluble formazan crystals (purple color), by the succinate dehydrogenase enzymes present in viable cells [26]. The data were performed using the L929 fibroblast lineage, acquired from the Rio de Janeiro Cell Bank (BCRJ, Rio de Janeiro, Brazil), being plated on 96-well plates in an amount of 10,000 cells per hole against different concentrations of the AgNPs-KP $\left(0.01-3 \mathrm{mg} \mathrm{mL}^{-1}\right)$ which were incubated at $37{ }^{\circ} \mathrm{C}$ in an incubator with a humidified atmosphere and $5 \% \mathrm{CO}_{2}$. Positive and negative controls were represented by $0.10 \mathrm{~mol} \mathrm{~L}^{-1}$ hydrogen peroxide $\left(\mathrm{H}_{2} \mathrm{O}_{2}\right)$ and cells in Dulbecco's Modified Eagle Medium (DMEM), respectively. After the incubation period, $20 \mu \mathrm{L}$ was added to the wells of sterile solution containing MTT $\left(5 \mathrm{mg} \mathrm{mL}^{-1}\right.$ of $1 \times$ PBS) and the plates were incubated for another $4 \mathrm{~h}$. After, the medium was carefully removed and the formazan crystals dissolved by the addition of $200 \mu \mathrm{L}$ of dimethylsulfoxide (DMSO). Inhibition of cell growth was detected by measuring absorbance at $570 \mathrm{~nm}$ in an ELISA device.

Another method used for cytotoxic analysis was the neutral red method, according to the literature [27]. Thus, after $24 \mathrm{~h}$ of incubation, the treatments were removed and an incomplete medium with the dye was added at a concentration of $0.04 \mu \mathrm{g} \mathrm{mL}{ }^{-1}$ for $3 \mathrm{~h}$. Subsequently, the cells were washed to remove excess dye and then a solution containing $1 \%$ acetic acid, $50 \%$ ethanol and $49 \%$ water was added to break the cell structures. The reading was carried out in an ELISA reader with a wavelength of $540 \mathrm{~nm}$.

\subsection{Reactive Oxygen and Nitrogen Species}

To evaluate the presence of reactive oxygen species (ROS) inside the cell was used the Dichlorofluorescein (DCFH) assay, according to the literature [28], through the addition of dichlorofluorescein acetate (DCFH-DA) to the cell. Within cells, this molecule is deacetylated by the action of intracellular esterase enzymes [29]. This reaction, in turn, forms a non-fluorescent product, 41-dihydrochlorofluorescein (DCFH). DCFH in the presence of reactive species is oxidized to a highly fluorescent form of dichlorofluorescein (DCF). Thus, the greater the fluorescence detected by the greater absorbance assessed by the fluorimeter, the greater the occurrence of oxidizing compounds $\left(\mathrm{H}_{2} \mathrm{O}_{2}\right)$. For the analysis of the total rates of ROS in a supernatant sample, the DCFH-DA reagent was diluted in ethyl alcohol [30].

Nitrite, a stable NO metabolite, was determined by the Griess method. The reagent was prepared from $0.23 \mathrm{~g}$ of sulfanilamide plus 0.012 of N(1-naphthyl) ethylenediamine dissolved in $10 \mathrm{~mL}$ of phosphoric acid. Initially, $100 \mu \mathrm{L}$ of the sample supernatant was incubated with an equal volume of Griess reagent and the absorbance was measured at $540 \mathrm{~nm}$ after $30 \mathrm{~min}$ of incubation at room temperature $\left(25 \pm 2{ }^{\circ} \mathrm{C}\right)$ [31]. 


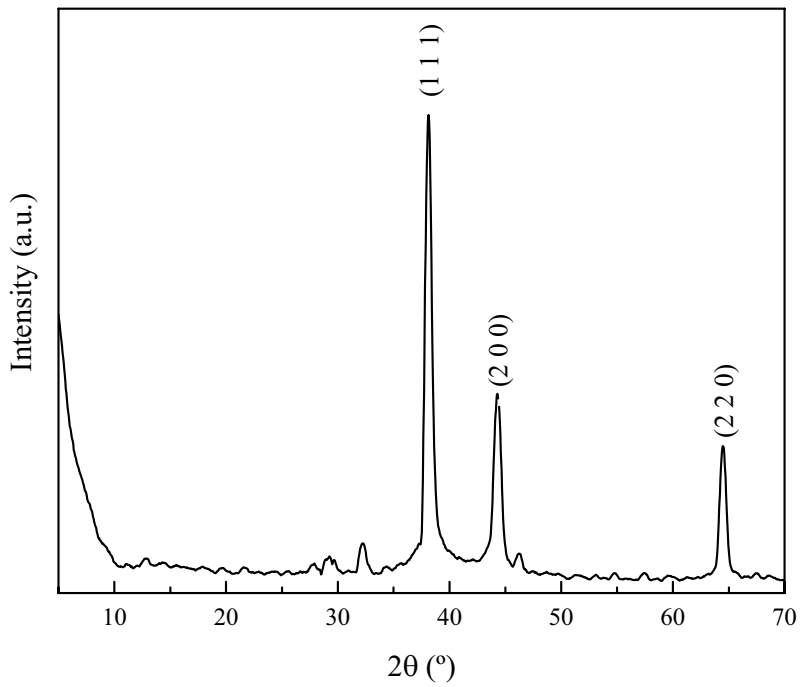

Fig. 3 XRD pattern diffractogram of silver nanoparticles synthesized from Klebsiella pneumoniae (AgNPs-KP)

\section{Results and Discussion}

\subsection{Characterization of the AgNPs-KP}

Figure 3 shows the diffractogram patterns of the AgNPs$\mathrm{KP}$, where it was possible to confirm the presence of silver at peaks $38.12^{\circ} ; 44.30^{\circ}$ and $64.47^{\circ}$ corresponding to the (111), (200), (220) planes of face-centered cubic (FCC) Ag respectively, according to ICDD (database \#04-0783 card number). Moreover, the peaks $32.09^{\circ}$ and $46.32^{\circ}$ correspond to $\mathrm{AgNO}_{3}$, which was not reduced consequently remaining in the sample in a small amount [32].

Moreover, the average size of crystalline of AgNPs-KP was determined using the Scherrer's formula (Eq. 1) [33] from the excessive reflectance (111) getting around $32 \mathrm{~nm}$.

$\mathrm{D}=\frac{\mathrm{k} \cdot \lambda}{\beta \cos (\theta)}$

where: $\mathrm{D}=$ average crystallite size $(\mathrm{nm}), \mathrm{k}=$ constant depending on the particle shape $(\mathrm{k}=0.9), \lambda=$ wavelength of electromagnetic radiation $(0.15418 \mathrm{~nm}), \Theta=$ diffraction angle $\left({ }^{\circ}\right)$, and $\beta=$ full width at half maximum (FWHM) of the peak diffraction.

Figure 4 represents the FTIR spectrum of AgNPs synthesized from Klebsiella pneumoniae (ATCC 700603) and Aloe vera extract, where some specific stretching was identified, such as [34]: (a) at $3450 \mathrm{~cm}^{-1}$ can be assigned to $-\mathrm{OH}$ group; (b) $1640 \mathrm{~cm}^{-1}$ may be assigned to $\mathrm{C}=\mathrm{O}$ stretching (ketone compound) of the precursors; (c) $1383 \mathrm{~cm}^{-1}$ to $\mathrm{O}-\mathrm{H}$ bend of the alcoholic group from phenol or tertiary alcohol compounds; and (d) $900 \mathrm{~cm}^{-1}$ can be assigned to $\mathrm{AgO}-\mathrm{O}$ stretching, confirming the biosynthesis success of

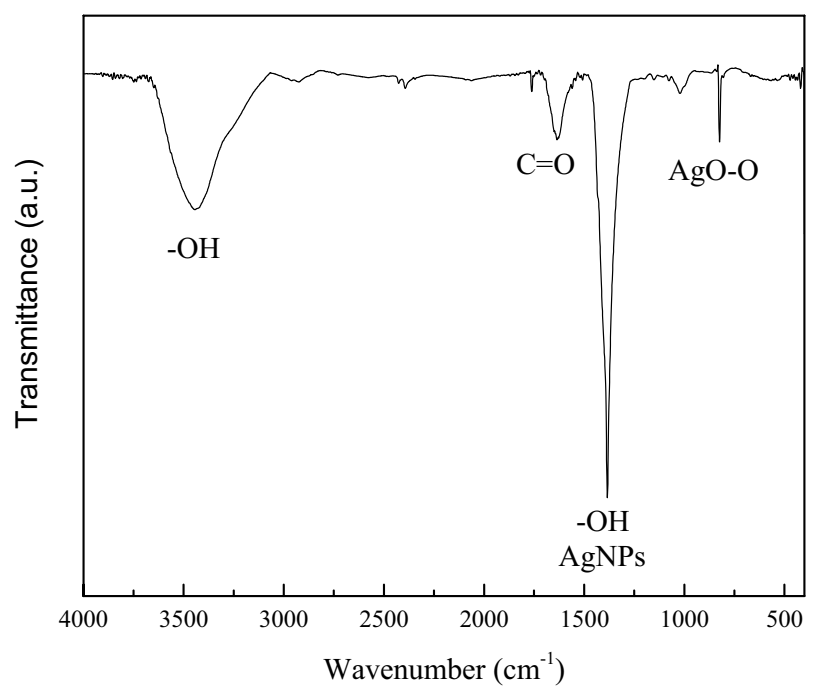

Fig. 4 Fourier transform infrared spectrum of silver nanoparticles synthesized from Klebsiella pneumoniae (AgNPs-KP)

the AgNPs. Moreover, the strong peak for $1640 \mathrm{~cm}^{-1}$ may be due to the formation of silver nanoparticles from Klebsiella pneumoniae and metallic precursor, indicating the reduction of silver nanoparticles was as a result of biomolecules present in the Klebsiella pneumoniae [35]. It is noteworthy that due to the use of an MHB solution with the bacteria and the metallic precursor, it was not possible to characterize by FTIR spectrum.

A Fig. 5a shows the micrograph of AgNPs-KP, indicating heterogeneous and rough surface, with a series of cavities and porosity with around $35 \mathrm{~nm}$, according to the literature [36], while Fig. 2b represents the elementary composition (\% weight) by EDS, indicating the presence of oxygen (13.39\%), silver (76.75\%), and chlorine $(9.86 \%)$, confirming the effectiveness of the biosynthesis process of silver nanoparticles.

Figure 6 shows the particle size distribution of the AgNPs-KP, indicating a good homogeneity of particle size distribution with an Ag nanoparticles size was in the range of $25-55 \mathrm{~nm}$. Moreover, the $100 \%$ of measured particles (highest fraction of AgNPs-KP) was $38.9 \mathrm{~nm}$, according to the SEM analysis.

\subsection{Inhibitory and Bactericidal Activity}

Table 1 showed the inhibitory and bactericidal activity for AgNPs-KP and AgNPs-AV. For all multiresistant bacterial strains tested, AgNPs-KP and AgNPs-AV confirmed the presence of inhibitory activity and bacterial killing. The MIC of AgNPs-AV ranged from $4.88 \mu \mathrm{g} \mathrm{mL}^{-1}$ to $9.76 \mu \mathrm{g} \mathrm{mL}^{-1}$ and the MBC ranged from $39.06 \mu \mathrm{g} \mathrm{mL}^{-1}$ to $78.12 \mu \mathrm{g} \mathrm{mL}^{-1}$. The MIC of AgNPs-KP ranged from $1.22 \mu \mathrm{g} \mathrm{mL}^{-1}$ to $9.76 \mu \mathrm{g} \mathrm{mL}^{-1}$ and $\mathrm{MBC}$ ranged from 


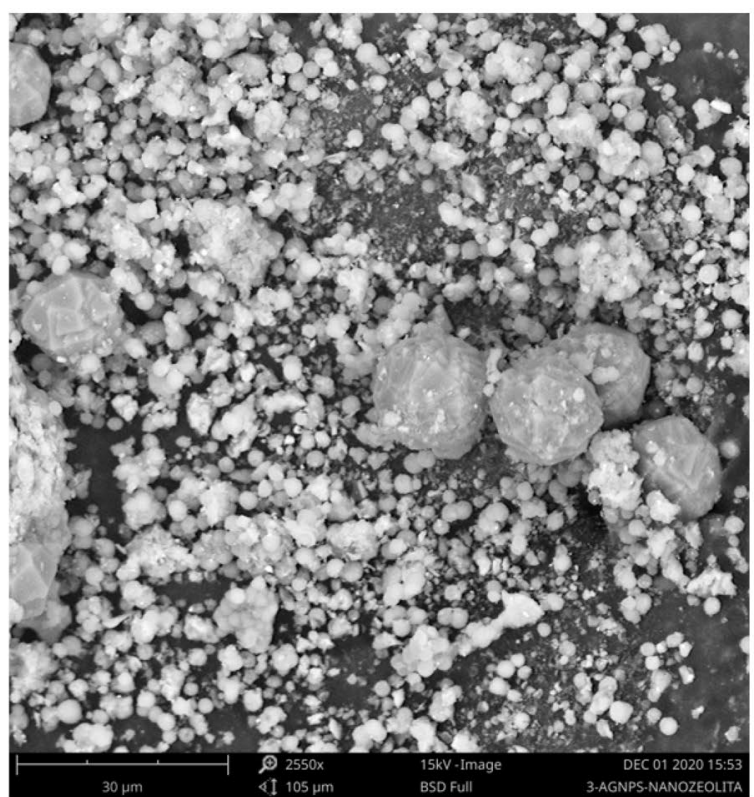

(a)

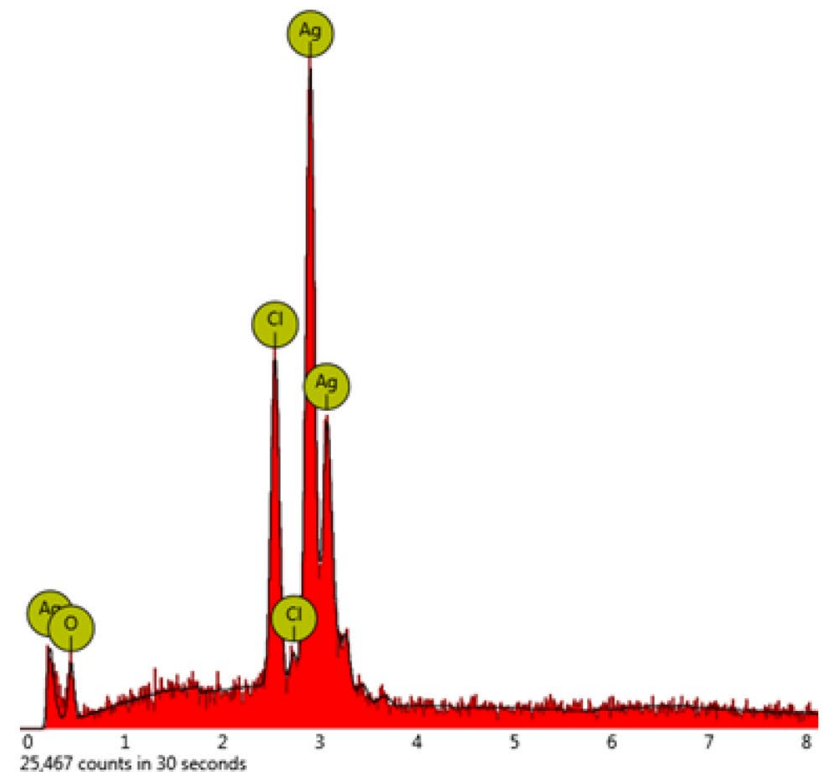

(b)

Fig. 5 a SEM micrograph with $2550 \times$ magnification and b elementary composition (\% weight) obtained by EDS analysis of silver nanoparticles synthesized from Klebsiella pneumoniae (AgNPs-KP)

$4.88 \mu \mathrm{g} \mathrm{mL}^{-1}$ to $39.06 \mu \mathrm{g} \mathrm{mL} \mathrm{m}^{-1}$. Thus, AgNPs synthesized from Klebsiella pneumoniae (ATCC 700603) showed significantly lower values for inhibition and bacterial killing, when compared to AgNPs synthesized from Aloe vera extract. However, to some bacterial strains (KpC 2102, 2104 and 2106), the values are similar to those of AgNPs-AV and in one bacterial strain ( $\mathrm{KpC} 2109)$ it is higher Moreover,

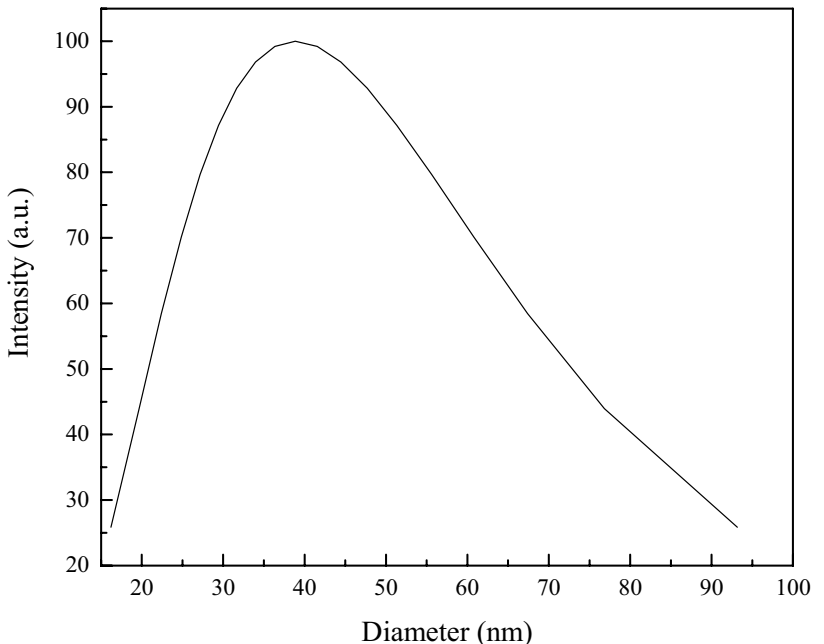

Fig. 6 DLS size distribution characterization of silver nanoparticles synthesized from Klebsiella pneumoniae (AgNPs-KP)

AgNPs-AV presented more stable values. Therefore, AgNPs synthesized using other precursors demonstrate lower MIC and MBC values compared to AgNPs-KP, where potent bacterial activity in low concentration corroborates with the hypothesis about biocompatibility [37].

\subsection{Cytotoxicity}

Figure 7a represents the results of the MTT colorimetric test, where it was possible to verify the decrease in cell viability starts from the concentration of $0.3 \mathrm{mg} \mathrm{mL}^{-1}$ of AgNPs-KP, with cytotoxicity varying from $16 \%$ to $82.7 \%$ depending on the concentration used. Moreover, according to results found in the literature, AgNPs-KP only showed cytotoxicity in the higher concentrations compared to other AgNPs that showed cytotoxicity at low concentrations. the results of the neutral red colorimetric test, where the cytotoxicity in the three highest concentrations $\left(0.3,1\right.$ and $\left.3 \mathrm{mg} \mathrm{mL}^{-1}\right)$, indicated the reduction of the viability around $38 \%$. Moreover, it was possible to notice a concentration/dependence on the number of viable cells when compared to the negative control Fig. $7 b$. Similar results were reported in evaluating the effect of this nanomaterial on different cell lines. Such as rat hepatocytes (10-50 $\mu \mathrm{g} \mathrm{mL}^{-1}$ ), alveolar macrophages (10-75 $\mu \mathrm{g} \mathrm{mL}^{-1}$ ), dermal fibroblasts $\left(30 \mu \mathrm{g} \mathrm{mL}^{-1}\right)$, and germinal stem cells $\left(10 \mu \mathrm{g} \mathrm{mL}^{-1}\right)$ [38-42]. Orlowski et al. (2018) [43] presented AgNPs with low toxicity in L929 fibroblasts, showing a concentration-dependent decrease in viability. In the same study, it was seen that the smaller the size of the nanomaterial, the greater the number of cells undergoing apoptosis and necrosis. Skladanowski et al. (2016) [44] also tested the biocompatibility in the L929 lineage, with results similar to ours regarding the concentrations tested and the percentage 
Table 1 MIC and MBC determination for AgNPs-KP and AgNPs-AV

\begin{tabular}{|c|c|c|c|c|}
\hline Clinical isolate & $\begin{array}{l}\mathrm{MIC}\left(\mu \mathrm{g} \mathrm{mL}^{-1}\right)- \\
\text { AgNPs-KP }\end{array}$ & $\begin{array}{l}\text { MIC }\left(\mu \mathrm{g} \mathrm{mL}^{-1}\right)- \\
\text { AgNPs-AV }\end{array}$ & $\begin{array}{l}\text { MBC }\left(\mu g \mathrm{~mL}^{-1}\right)- \\
\text { AgNPs-KP }\end{array}$ & $\begin{array}{l}\mathrm{MBC}(\mu \mathrm{g} \\
\left.\mathrm{mL}^{-1}\right)- \\
\text { AgNPs-AV }\end{array}$ \\
\hline KpC $2101^{*}$ & 2.44 & 9.76 & 9.76 & 78.12 \\
\hline КрС 2102* & 9.76 & 9.76 & 39.06 & 78.12 \\
\hline КрС 2103* & 2.44 & 9.76 & 9.76 & 78.12 \\
\hline KpC 2104* & 9.76 & 9.76 & 39.06 & 78.12 \\
\hline КрС 2105* & 1.22 & 4.88 & 4.88 & 39.06 \\
\hline KpC 2106* & 9.76 & 9.76 & 39.06 & 78.12 \\
\hline KpC 2107* & 2.44 & 9.76 & 9.76 & 78.12 \\
\hline КрС $2108^{*}$ & 2.44 & 4.88 & 9.76 & 39.06 \\
\hline КрС 2109* & 9.76 & 4.88 & 39.06 & 39.06 \\
\hline
\end{tabular}

* Code of each clinical isolate used in the assay

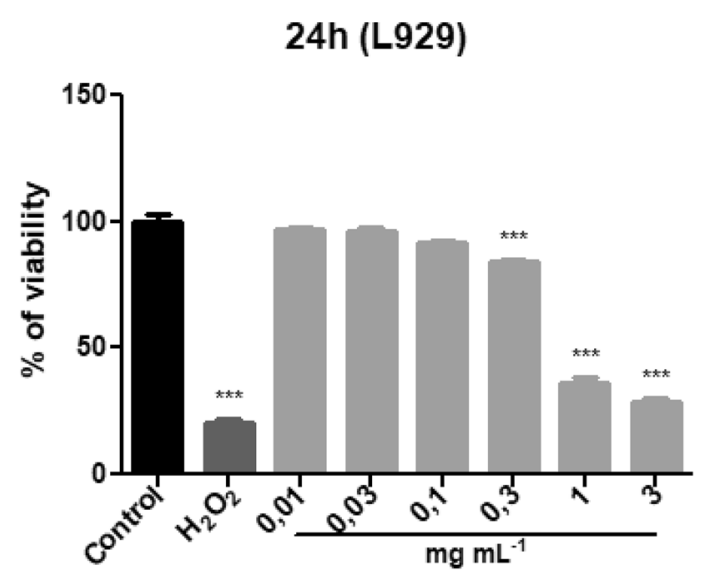

(a)

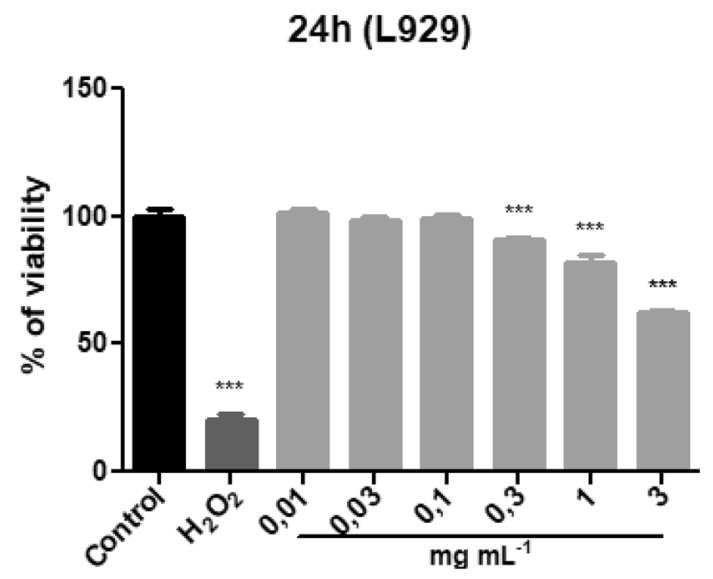

(b)

Fig. 7 a Evaluation of cytotoxicity in the MTT and b Neutral Red assays after $24 \mathrm{~h}$ of incubation using the of silver nanoparticles synthesized from Klebsiella pneumoniae (AgNPs-KP) of dead cells. The mechanism of cytotoxicity of AgNPs is described by the metal ion action on mitochondrial damage through interactions with thiol groups of the inner membrane, in addition to the alteration of normal metabolic activities [45, 46].

\subsection{Production Reactive Species}

Figure 8a demonstrates the tested concentrations of AgNPsKP did not increase ROS levels. This result can be explained because non-tumor cells are characterized by having high antioxidant activity, which is due to the presence of high levels of catalase, whose action represents an important defense mechanism for ROS elimination [47]. In the study of Barcinska et al. (2018) [48] the effect of ROS by AgNPs was more significant in tumor cells compared to normal cells from the same tissue. In the Fig. 8b, the concentration that caused an increase in the levels of reactive nitrogen species (RNS) was the highest, at $3 \mathrm{mg} \mathrm{mL}^{-1}$. The increase in NO levels from AgNPs generates aberrations in cell metabolism, increased nitro-oxidative stress, and mediating cell death [49]. This generation of NO has important anticancer activity in ovarian, pancreas, and colon cancer cells [50-52].

\section{Conclusion}

In our study, we confirmed that AgNPs were obtained after the reduction of silver nitrate by $K$. pneumoniae. The synthesized AgNPs were characterized by morphological, XRD and FTIR properties that revealed the crystalline nature of the AgNPs. SEM micrograph indicated a heterogeneous and rough surface, with a series of cavities and porosity with around $35 \mathrm{~nm}$, and EDS indicated an elemental composition of oxygen (13.39\%), silver (76.75\%) and chlorine (9.86\%), confirming the biosynthesis of AgNPs. DLS results indicated a good homogeneity with highest fraction of AgNPs-KP at 


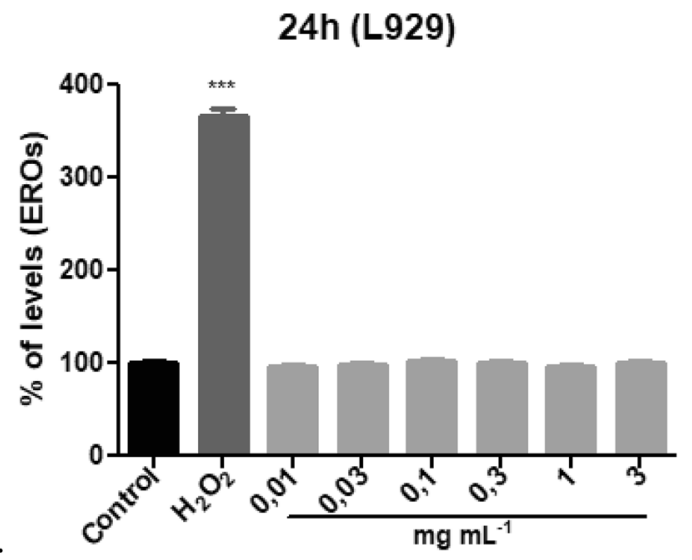

(a)

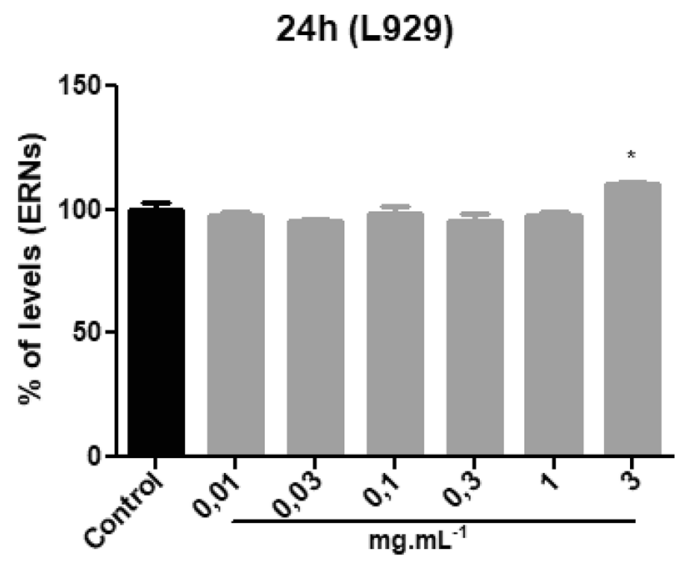

(b)

Fig. 8 a Evaluation of ROS and $\mathbf{b}$ RNS production using the silver nanoparticles synthesized from Klebsiella pneumoniae (AgNPs-KP)

$38.9 \mathrm{~nm}$. The assays showed that AgNPs-KP has potent antimicrobial activity at low concentration against antimicrobial resistant pathogens when compared to AgNPs produced by other methods, both chemical and biological, described in the literature and also proven in the comparison test with AgNPs synthesized by Aloe vera, even with unstable values that vary with each bacterial strain tested compared to other AgNPs, as AgNPs-KP were able to inhibit bacterial growth at a minimum concentration of $9.76 \mu \mathrm{g} \mathrm{mL}^{-1}$ and kill the bacterial cell at a minimum concentration of $39.06 \mu \mathrm{g} \mathrm{mL}^{-1}$. AgNPs-KP in concentrations of 10,30 and $100 \mu \mathrm{g} \mathrm{mL}^{-1}$ did not show any cytotoxic properties for the fibroblast L929 cell line and the viability of these target cells remained at the same level as the untreated controls. The cytotoxic effect was observed in high concentrations of AgNPs from $300 \mu \mathrm{g} \mathrm{m}^{-1}$. AgNPs-KP did not produce ROS about the analyzed concentrations and RNS production was only in the highest concentration of $3000 \mu \mathrm{g} \mathrm{mL}^{-1}$. Based on the data obtained, we conclude that AgNPs biosynthesized by
Klebsiella pneumoniae ATCC 700603 have potential medical applicability as a promising antimicrobial agent, in addition to being safer. Its synthesis is effective, simple, fast and inexpensive.

Acknowledgements We thank the Polytechnical School of Chemical Engineering at University of São Paulo 537 (USP, Brazil-SP) and Franciscan University (UFN, Brazil-RS) for the support and assistance to carry out the present work. This work received financial support from the Foundation for Research of the State of Rio Grande do Sul (FAPERGS-Project 19/2551-0001606-9).

Author Contributions GC: Conceptualization, Validation, Writingreview and editing. PCLM: Conceptualization, Writing-review and editing. ARV: Conceptualization, Data curation, Formal analysis, Investigation, Validation, Writing-original draft, Writing-review and editing. GPP: Conceptualization, Data curation, Writing-review and editing. DCRE: Conceptualization, Writing-review and editing. BSV: Conceptualization, Validation, Writing-review and editing. WLDS: Conceptualization, Data curation, Formal analysis, Investigation, Validation, Writing-original draft, Writing-review and editing.

Data Availability The data that support the findings of this study are available on request from the corresponding author.

Code Availability Not applicable.

\section{Declarations}

Conflict of interest The authors declare that they have no known competing financial interests or personal relationships that could have appeared to influence the work reported in this paper.

Ethical Approval Not applicable.

Consent to Participate Not applicable.

Consent to Publish All authors read and approved the final manuscript.

\section{References}

1. WHO - World Antimicrobial Awareness Week. https://www. who.int/campaigns/world-antimicrobial-awareness-week/2020. [Acessed 25 August 2021]

2. L. Cantas, S.Q. Shah, L.M. Cavaco, C.M. Manaia, F. Walsh, M. Popowska, H. Garelick, H. Bürgmann, H.A. Sørum, A brief multidisciplinary review on antimicrobial resistance in medicine and its linkage to the global environmental microbiota. Front. Microbiol. 4, 1-13 (2013). https://doi.org/10.3389/fmicb.2013.00096

3. M.H. Siddique, B. Aslam, M. Imran, A. Ashraf, H. Nadeem, S. Hayat, M. Khurshid, M. Afzal, I.R. Malik, M. Shahzad, U. Qureshi, Z.U.H. Khan, S. Muzammil, Effect of silver nanoparticles on biofilm formation and eps production of multidrug-resistant Klebsiella pneumoniae. Biomed. Res. Int. 2020, 1-9 (2020). https://doi.org/10.1155/2020/6398165

4. Z.X. Tang, B.F. Lv, MgO nanoparticles as antibacterial agent: preparation and activity. Braz. J. Chem. Eng. 31, 591-601 (2014). https://doi.org/10.1590/0104-6632.20140313s00002813

5. M. Mani, R. Harikrishnan, P. Purushothaman, S. Pavithra, P. Rajkumar, S. Kumaresan, D.A. Al-Farraj, M.S. Elshikh, B. Balasubramanian, K. Kaviyarasu, Systematic green synthesis of silver 
oxide nanoparticles for antimicrobial activity. Environ. Res. 202, 111627-111635 (2021). https://doi.org/10.1016/j.envres.2021. 111627

6. R. Renuka, K.R. Devi, M. Sivakami, T. Thilagavathi, R. Uthrakumar, K. Kaviyarasu, Biosynthesis of silver nanoparticles using phyllanthus emblica fruit extract for antimicrobial application. Biocatal. Ag. Biot. 24, 101567-101572 (2020). https://doi.org/ 10.1016/j.bcab.2020.101567

7. M. Mani, M.K. Okla, S. Selvaraj, A.R. Kumar, S. Kumaresan, A. Muthukumaran, K. Kaviyarasu, M.A. El-Tayeb, Y.B. Elbadawi, K.S. Almaary, B.M.A. Almunqedhi, M.S. Elshikh, A novel biogenic Allium cepa leaf mediated silver nanoparticles for antimicrobial, antioxidant, and anticancer effects on MCF-7 cell line. Environ. Res. 198, 111199-111207 (2021). https://doi.org/10. 1016/j.envres.2021.111199

8. M. Mani, S. Pavithra, K. Mohanraj, S. Kumaresan, S.S. Alotaibi, M.M. Eraqi, A.D. Gandhi, R. Babujanarthanam, M. Maaza, K. Kaviyarasu, Studies on the spectrometric analysis of metallic silver nanoparticles (Ag NPs) using Basella alba leaf for the antibacterial activities. Environ. Res. 199, 111274-111281 (2021). https://doi.org/10.1016/j.envres.2021.111274

9. M. Bawskar, S. Deshmukh, S. Bansod, A. Gade, M. Rai, Comparative analysis of biosynthesised and chemosynthesised silver nanoparticles with special reference to their antibacterial activity against pathogens. IET Nanobiotechnol. 9, 107-113 (2015). https://doi.org/10.1049/iet-nbt.2014.0032

10. S. Scandorieiro, L.C. Camargo, C.A.C. Lancheros, S.F. YamadaOgatta, C.V. Nakamura, A.G. Oliveira, C.G.T.J. Andrade, N. Duran, G. Nakazato, R.K.T. Kobayashi, Synergistic and additive effect of oregano essential oil and biological silver nanoparticles against multidrug-resistant bacterial strains. Front. Microbiol. 7, 1-4 (2016). https://doi.org/10.3389/fmicb.2016.0076

11. A.A. Menazea, A.M. Ismail, A. Samy, Novel green synthesis of zinc oxide nanoparticles using orange waste and its thermal and antibacterial activity. J. Inorg. Organomet. Polym. 31, 4250-4259 (2021). https://doi.org/10.1007/s10904-021-02074-2

12. A. Singh, P.K. Gautam, A. Verma, V. Singh, P.M. Shivapriya, S. Shivalkar, A.K. Sahoo, S.K. Samanta, Green synthesis of metallic nanoparticles as effective alternatives to treat antibiotics resistant bacterial infections: A review. Biotechnol. Rep. 25, 1-11 (2020). https://doi.org/10.1016/j.btre.2020.e00427

13. S. Akbar, I. Tauseef, F. Subhan, N. Sultana, I. Khan, U. Ahmed, K.S. Haleem, An overview of the plant-mediated synthesis of zinc oxide nanoparticles and their antimicrobial potential. Inorg. Nano. Metal Chem. 50, 257-271 (2020). https://doi.org/10.1080/24701 556.2019 .1711121

14. M.A. Quinteros, J.O. Bonilla, S.V. Alborés, L.B. Villegas, P.L. Páez, Biogenic nanoparticles: Synthesis, stability and biocompatibility mediated by proteins of Pseudomonas aeruginosa. Colloid. Surf. B 184, 110517-110522 (2019). https://doi.org/10.1016/j. colsurfb.2019.110517

15. E.N. Gecer, Green synthesis of silver nanoparticles from Salvia aethiopis $\mathrm{L}$. and their antioxidant activity. J. Inorg. Organomet. Polym. 31, 4402-4409 (2021). https://doi.org/10.1007/ s10904-021-02057-3

16. G.N. Rajivgandhi, C.C. Kanisha, S. Vijayakumar, N.S. Alharbi, S. Kadaikunnan, J.M. Khaled, K.F. Alanzi, W.J. Li, Enhanced anti-biofilm activity of facile synthesized silver oxide nanoparticles against K. pneumoniae. J. Inorg. Organomet. Polym. 31, 3921-3933 (2021). https://doi.org/10.1007/s10904-021-02013-1

17. C. Nirmala, M. Sridevi, Characterization, antimicrobial and antioxidant evaluation of biofabricated silver nanoparticles from Endophytic Pantoea anthophila. J. Inorg. Organomet. Polym. 31, 3711-3725 (2021). https://doi.org/10.1007/s10904-021-01974-7

18. P.P. Fu, Q. Xia, H.M. Hwang, P.C. Ray, H. Yu, Mechanisms of nanotoxicity: Generation of reactive oxygen species. J. Food.
Drug Anal. 22, 64-75 (2014). https://doi.org/10.1016/j.jfda. 2014.01.005

19. M. Skladanowski, P. Golinska, K. Rudnicka, H. Dahm, M. Rai, Evaluation of cytotoxicity, immune compatibility and antibacterial activity of biogenic silver nanoparticles. Med. Microbiol. Immun. 205, 603-613 (2016). https://doi.org/10.1007/ s00430-016-0477-7

20. S. Valsalam, P. Agastian, M.V. Arasu, N.A. Al-Dhabi, A.M. Ghilan, K. Kaviyarasu, B. Ravindran, S.W. Chang, S. Arokiyaraj, Rapid biosynthesis and characterization of silver nanoparticles from the leaf extract of Tropaeolum majus L. and its enhanced in-vitro antibacterial, antifungal, antioxidant and anticancer properties. J. Photoch. Photobio. B 191, 65-74 (2019). https://doi.org/ 10.1016/j.jphotobiol.2018.12.010

21. A.D. Gandhi, K. Kaviyarasu, N. Supraja, R. Velmurugan, G. Suriyakala, R. Babujanarthanam, Y. Zang, K. Soontarapa, K.S. Almaary, M.S. Elshikh, T.W. Chen, Annealing dependent synthesis of cyto-compatible nano-silver/calcium hydroxyapatite composite for antimicrobial activities. Arab. J. Chem. 14(11), 103404-103413 (2021). https://doi.org/10.1016/j.arabjc.2021. 103404

22. K. Anand, K. Kaviyarasu, S. Muniyasamy, S.M. Roopan, R.M. Gengan, A.A. Chuturgoon, Bio-synthesis of silver nanoparticles using agroforestry residue and their catalytic degradation for sustainable waste management. J. Clust. Sci. 28, 2279-2291 (2017). https://doi.org/10.1007/s10876-017-1212-2

23. S.P. Chandran, M. Chaudhary, R. Pasricha, A. Ahmad, M. Sastry, Synthesis of gold nanotriangles and silver nanoparticles using Aloe vera plant extract. Biotechnol. Prog. 22, 577-583 (2006). https://doi.org/10.1021/bp0501423

24. A.R. Shahverdi, S. Minaeian, H.R. Shahverdi, H. Jamalifar, A.A. Nohi, Rapid synthesis of silver nanoparticles using culture supernatants of Enterobacteria: A novel biological approach. Process Biochem. 42, 919-923 (2007). https://doi.org/10.1016/j.procbio. 2007.02.005

25. BrCAST. Brazilian Committee on Antimicrobial Susceptibily Testing. Antimicrobial sensitivity test. EUCAST disk-broadcast method. hhttp://brcast.org.br. [Acessed 28 August 2021].

26. T. Mosmann, Rapid colorimetric assay for cellular growth and survival: application to proliferation and cytotoxicity assays. J. Immunol. Methods 65, 55-63 (1983). https://doi.org/10.1016/ 0022-1759(83)90303-4

27. G. Repetto, A. Peso, J.L. Zurita, Neutral red uptake assay for the estimation of cell viability/cytotoxicity. Nat. Protoc. 3, 1125-1131 (2008). https://doi.org/10.1038/nprot.2008.75

28. H. Sauer, K. Wefer, V. Vetrugno, M. Pocchiari, C. Gissel, A. Sachinidis, J. Hescheler, M. Wartenberg, Regulation of intrinsic prion protein by growth factors and TNFalpha: the role of intracellular reactive oxygen species. Free Radical Biol. Med. 35, 586-594 (2003). https://doi.org/10.1016/s0891-5849(03)00360-5

29. C. Rota, C.F. Chignell, R.P. Mason, Evidence for free radical formation during the oxidation of $2^{\prime}-7^{\prime}$-dichlorofluorescin to the fluorescent dye $2^{\prime}-7^{\prime}$-dichlorofluorescein by 68 horseradish peroxidase: possible implications for oxidative stress measurements. Free Radical Biol. Med. 27, 873-881 (1999). https://doi.org/10. 1016/s0891-5849(99)00137-9

30. B. Halliwell, M. Whiteman, Measuring reactive species and oxidative damage in vivo and in cell culture: how should you do it and what do the results mean? Br. J. Pharmacol. 142, 231-255 (2004). https://doi.org/10.1038/sj.bjp.0705776

31. W.S. Choi, P. Shin, J. Lee, G. Kim, 2012 The regulatory effect of veratric acid on NO production in LPS-stimulated RAW264.7 macrophage cells. Cell Immunol. 280, 164-170 (2012). https:// doi.org/10.1016/j.cellimm.2012.12.007

32. M. Kooti, S. Saiahi, H. Motamedi, Fabrication of silver-coated cobalt ferrite nanocomposite and the study of its antibacterial 
activity. J. Magn. Magn. Mater. 333, 138-143 (2012). https://doi. org/10.1016/j.jmmm.2012.12.038

33. C. Rosa, F. Auriemma, Crystals and crystallinity in polymers: diffraction analysis of ordered and disordered crystals, 1st edn. (Wiley, Nova Jersey, 2014), pp. 123-184

34. N. Mehta, K.S. Laddha, A modified method for isolation of Rhein from Senna. Indian J. Pharm. Sci. 71, 128-129 (2009). https://doi. org/10.4103/0250-474X.54275

35. A. Sobhani-Nasabi, M. Behpour, Synthesis and characterization of $\mathrm{AgO}$ nanostructures by precipitation method and its photocatalyst application. J. Mater. Sci. Mater. Electron. 27, 1191-1196 (2016). https://doi.org/10.1007/s10854-015-3873-7

36. F. Shahryari, Z. Rabiei, S. Sadighian, Antibacterial activity of synthesized silver nanoparticles by sumac aqueous extract and silver-chitosan nanocomposite against Pseudomonas syringae pv. Syringae. J. Plant Pathol. 102, 469-475 (2020). https://doi.org/10. 1007/s42161-019-00478-1

37. P.C.L. Muraro, S.R. Mortari, B.S. Vizzotto, G. Chuy, C. Dos Santos, L.F.W. Brum, W.L. Da Silva, Iron oxide nanocatalyst with titanium and silver nanoparticles: Synthesis, characterization and photocatalytic activity on the degradation of Rhodamine B dye. Sci. Rep. 10, 3055-3063 (2020). https://doi.org/10.1038/ s41598-020-59987-02

38. S. Arora, J. Jain, J.M. Rajwade, K.M. Paknikar, Interactions of silver nanoparticles with primary mouse fibroblasts and liver cells. Toxicol. Appl. Pharm. 236, 310-318 (2009). https://doi.org/10. 1016/j.taap.2009.02.020

39. L. Braydich-Stolle, S. Hussain, J.J. Schlager, M.C. Hofmann, In vitro cytotoxicity of nanoparticles in mammalian germline stem cells. Toxicol. Sci. 88, 412-419 (2005). https://doi.org/10.1093/ toxsci/kfi256

40. C. Carlson, S.M. Hussain, A.M. Schrand, L.K. Braydich-Stolle, K.L. Hess, R.L. Jones, J.J. Schlager, Unique cellular interaction of silver nanoparticles: size-dependent generation of reactive oxygen species. J. Phys. Chem. B 112, 13608-13619 (2008). https://doi. org/10.1021/jp712087m

41. S.M. Hussain, K.L. Hess, J.M. Gearhart, K.T. Geiss, J.J. Schlager, In vitro toxicity of nanoparticles in BRL 3A rat liver cells. Toxicol. In Vitro 19, 975-983 (2005). https://doi.org/10.1016/j.tiv. 2005.06.034

42. S. Kim, J.E. Choi, J. Choi, K.H. Chung, K. Park, J. Yi, D.Y. Ryu, Oxidative stress-dependent toxicity of silver nanoparticles in human hepatoma cells. Toxicol. In Vitro 23, 1076-1084 (2009). https://doi.org/10.1016/j.tiv.2009.06.001

43. P. Orlowski, M. Zmigrodzka, E. Tomaszewska, K. RanoszekSoliwoda, M. Czupryn, M. Antos-Bielska, J. Szemraj, G. Celichowski, J. Grobelny, M. Krzyzowska, Tannic acid-modified silver nanoparticles for wound healing: the importance of size. Int. J. Nanomed. 13, 991-1007 (2018). https://doi.org/10.2147/IJN. S154797
44. J. Grommes, O. Soehnlein, Contribution of neutrophils to acute lung injury. Mol. Med. 17, 293-307 (2011). https://doi.org/10. 2119/molmed.2010.00138

45. M.R. Almofti, T. Ichikawa, K. Yamashita, H. Terada, Y. Shinohara, Silver ion induces a cyclosporine a-insensitive permeability transition in rat liver mitochondria and release of apoptogenic cytochrome C. J. Biochem. 134, 43-49 (2003). https://doi.org/10. $1093 / \mathrm{jb} / \mathrm{mvg} 111$

46. J.C. Wataha, P.E. Lockwood, A. Schedle, M. Noda, S. Bouillaguet, $\mathrm{Ag}, \mathrm{Cu}, \mathrm{Hg}$ and $\mathrm{Ni}$ ions alter the metabolism of human monocytes during extended low-dose exposures. J. Oral. Rehabil. 29, 133 139 (2002). https://doi.org/10.1046/j.1365-2842.2002.00845.x

47. M. D'Errico, T. Lemma, A. Calcagnile, L. Proietti de Santis, E. Dogliotti, Cell type and DNA damage specific response of human skin cells to environmental agents. Mutat. Res. 614, 37-47 (2007). https://doi.org/10.1016/j.mrfmmm.2006.06.009

48. E. Barcinska, J. Wierzbicka, A. Zauszkiewicz-Pawlak, D. Jacewicz, A. Dabrowska, I. Inkielewicz-Stepniak, Role of oxidative and nitro-oxidative damage in silver nanoparticles cytotoxic effect against human pancreatic ductal adenocarcinoma cells. Oxid. Med. Cell. Longev. 2018, 1-15 (2018). https://doi.org/10.1155/ 2018/8251961

49. M.L.T. Teoh, M.P. Fitzgerald, T.J. Jensen, B.W. Futscher, F.E. Domann, Genetic and epigenetic inactivation of extracellular superoxide dismutase promotes an invasive phenotype in human lung cancer by disrupting ECM homeostasis. Mol. Cancer. Res. 10, 40-51 (2012). https://doi.org/10.1158/1541-7786. MCR-11-0501

50. M.L.T. Teoh, M.P. Fitzgerald, L.W. Oberley, F.E. Domann, Overexpression of extracellular superoxide dismutase attenuates heparanase expression and inhibits breast carcinoma cell growth and invasion. Cancer Res. 69, 6355-6363 (2009). https://doi.org/10. 1158/0008-5472.CAN-09-1195

51. M.L.T. Teoh, W. Sun, B.J. Smith, L.W. Oberley, J.J. Cullen, Modulation of reactive oxygen species in pancreatic cancer. Clin. Cancer Res. 13, 7441-7450 (2007). https://doi.org/10.1158/10780432.CCR-07-0851

52. I.N. Zelko, T.J. Mariani, R.J. Folz, Superoxide dismutase multigene family: a comparison of the CuZn-SOD (SOD1), Mn-SOD (SOD2), and EC-SOD (SOD3) gene structures, evolution, and expression. Free Radical. Bio. Med. 33, 337-349 (2002). https:// doi.org/10.1016/S0891-5849(02)00905-X

Publisher's Note Springer Nature remains neutral with regard to jurisdictional claims in published maps and institutional affiliations. 